\title{
AZ ISKOLÁK SZAKMAI FELÜGYELETE NÉMETORSZÁGBAN: HESSEN TARTOMÁNY PÉLDÁJA
}

\section{BIKICS GABRIELLA}

\author{
a Miskolci Egyetem Bölcsészettudományi Karának \\ egyetemi docense \\ bikicsg@gmail.com
}

\begin{abstract}
A magyar oktatáspolitika egyik legfontosabb új „,projektje“ a tanfelügyeleti rendszer reformja. A koncepció már körvonalazódott, jelenleg az elsö tanfelügyelök képzése folyik. Ezért indokolt a nemzetközi kitekintés, különösen egy olyan országra, amihez politikai, gazdasági és kulturális téren ezer szállal kötödtünk és kötődünk ma is. A szerzö bemutatja a német tanfelügyelet történetét, változásait és jelenlegi koncepcióját, különös tekintettel Hessen tartományra. Leirja a tanfelügyeleti látogatások menetét, módszereit, eszközeit és eredményeit. A német példa megismerése sok tanulsággal szolgálhat a magyar tanfelügyeleti rendszer számára.
\end{abstract}

\section{Tanfelügyelet és szakfelügyelet a magyar és a német terminológiában}

A szakfelügyelet rendszerét és a szakfelügyelő személyét mindenki az iskolához köti. Emlékeinkben megjelenik egy látogató, aki megnézte egy-egy tanárunk óráját és beszélgetett vele. Később a szakfelügyelő helyett az iskolába a szaktanácsadó járt, akinek a feladata az ellenőrzésről a tanácsadásra változott. Mostanában kezd körvonalazódni a magyar oktatásügyben egy újfajta szakfelügyeleti rendszer, aminek pontos részletei azonban még nem ismeretesek. A szakmai felügyelet elnevezés jóval általánosabb, szélesebb körü, az élet számos területére kiterjed, ahol szükséges az ellenörzés.

A német nyelvben a szakfelügyelet és a szakmai felügyelet ugyanaz a szó (Fachaufsicht), amit a jogi lexikon így definiál: „Az állam felügyeletet gyakorol az intézményei felett. A felügyeletre jogosult hatóság jogsértő vagy nem a célnak megfelelő tevékenység esetén jogosult a beavatkozásra."1 Németországban a szakmai felügyeletet az iskola vonatkozásában iskolafelügyeletnek (Schulaufsicht) hívják, amit a továbbiakban a magyar terminológiának megfelelően tanfelügyeletnek nevezek.

\footnotetext{
${ }^{1}$ Rechstlexikon-online: http://www.rechtslexikon-online.de Letöltve: 2013. 03. 27.
} 
Németországban mindenfajta állami felügyeletnek így a tanfelügyeletnek is általában három formáját különböztetik meg. Ezek szerepelnek az egyes tartományok iskolatörvényeiben. ${ }^{2}$

A tanfelügyelet formái: a szakfelügyelet/szakmai felügyelet (Fachaufsicht), a jogi felügyelet (Rechtsaufsicht), a szolgálati felügyelet (Dienstaufsicht) és a diákotthonok felügyelete. A szak- és a jogi felügyelet az iskola igazgatási és jogi rendszerének felügyeletét jelenti, annak teljes spektrumában. Egyes német tartományok iskolatörvényeiben külön (mint igazgatási és jogi felügyelet), másutt együtt (mint rendszerfelügyelet) szerepel. A szolgálati felügyelet az iskolában dolgozó személyek, elsősorban a pedagógusok tevékenységének felügyeletét jelenti, azonban ez nem vonatkozik a munkájuk minőségére. Továbbá ide tartozik még például Hessen tartományban a diákotthonok felügyelete. ${ }^{3}$

A tanfelügyelet jogi szabályozása az egyes német tartományok iskolatörvényeiben valósul meg, ${ }^{4}$ melyek többek között leírják a tanfelügyelet gyakorlásának módszerét is: Az iskola és az iskola igazgatójának ellenőrzését az iskolát ellenőrző látogatók, tanfelügyelök (Schulinspektor) végzik az iskolát ellenőrző tanfelügyeleti látogatás (Schulinspektion) keretében.

A német nyelvben a klasszikus értelemben vett „szakfelügyelöre” nincs szó, mert a felsorolt felügyeleti formák csak az iskolára, illetve személy szerint annak igazgatójára terjednek ki. A közvetlen külső ellenőrzés csak az iskolát és az iskolaigazgatót érinti, a pedagógusokat legfeljebb közvetett módon. Őket a belső ellenőrzéskor az igazgató látogatja.

\section{A német tanárképzés rendszerében alkalmazott pályaalkalmassági szürők}

Felmerülhet a kérdés, hogy szakfelügyelö híján hogyan lehet a nem megfelelő kompetenciákkal rendelkező tanárokat „felismerni”. Ök Németországban el sem jutnak a tanári állásig, mert a német tanárképzés rendszerébe számos pályaalkalmassági „szürő” van beépítve (Bikics, 2011). Ezekben az „éles” helyzetekben a jelölteket fokozatosan szembesítik a pedagóguspálya kihívásaival. Az alkalmatlan jelölteket vagy eltanácsolják vagy kudarcaikból okulva maguk ismerik fel alkalmatlanságukat, és módosítják pályaválasztásukat.

\footnotetext{
${ }^{2}$ Kultusministerkonferenz, Schulgesetze 2013 http://www.kmk.org/dokumentation/rechtsvorschriften-und-lehrplaene-der-laender/uebersichtschulgesetze.html Letöltve: 2013. 04. 16.

${ }^{3}$ Hessisches Schulgesetz (Hessen Iskolatörvénye) 2005, utolsó változata: 2012. Kultusministerkonferenz, Schulgesetze 2013.

http://www.kmk.org/dokumentation/rechtsvorschriften-und-lehrplaene-der-laender/uebersichtschulgesetze.html Letöltve: 2013. 04. 16.

${ }^{4}$ Kultusministerkonferenz, Schulgesetze 2013.

http://www.kmk.org/dokumentation/rechtsvorschriften-und-lehrplaene-der-laender/uebersichtschulgesetze.html Letöltve: 2013. 04. 16.
} 


\section{Pályaalkalmassági szürök a német tanárképzésben}

- Alkalmassági szürő az egyetemi tanulmányok megkezdése előtt különféle lehetséges módszerekkel (tesztek, elbeszélgetés, ajánlás, előzetes gyakorlati tapasztalatok stb.), amelyeknek alkalmazásáról a pedagógusképző intézmények saját hatáskörben döntenek.

- Iskolai gyakorlat az egyetemi tanulmányok során (időtartama eltérő lehet: több hetestől fél évesig).

- Államvizsga az egyetemi tanulmányok lezárására: számadás a tanárjelölt elméleti szaktárgyi és pedagógiai ismereteiről.

- Gyakornoki tevékenység (időtartama hosszú: másfél-két év, kezdetben felügyelt, majd fokozatosan egyre önállóbban végzett).

- Tanári képesítő vizsga a gyakornoki tanulmányok lezárására: reflexió a tanárjelölt elméleti ismereteinek és gyakorlati tanítási tapasztalatainak öszszekapcsolásáról.

- Pályakezdő tanári szakasz (egy-három év, rendszerint határozott idejü, részben vagy egészében ,próbaidős” munkaviszony, amit külön támogató rendszer segít, óralátogatásokkal, célzott továbbképzésekkel és személyre szóló tanácsadással).

A pályakezdés szakaszán túljutott, határozatlan idejü munkaviszonnyal rendelkező, gyakran nem alkalmazotti, hanem hivatalnoki státuszban álló tanárok esetében már fel sem merülhet, hogy egy pedagógus alkalmatlan a feladata ellátására, legfeljebb egyes területeken fejlesztésre szorul. A pedagógusok esetében a szakmai fejlesztést és minőségbiztosítást „kívülről” a szaktanácsadó, vagy „belülről” az igazgató valósítja meg.

\section{Külső és belső minőségbiztosítás}

Az egyes pedagógusok esetében a külső minőségbiztosítás nem „szakfelügyelő”, hanem szolgáltató rendszerben szaktanácsadó (Fachberater) útján történik, akinek feladata az óralátogatás és óramegbeszélés, a tanár továbbképzési szükségleteinek feltárása és megfelelő továbbképzések ajánlása. A szaktanácsadónak nem feladata az ellenőrzés, értékelés vagy minősítés. Németországban ez a szakértői rendszer jól müködik. Egy személyes példa egy német pedagógus elmondása szerint: Másfél évvel a szaktanácsadó nyugdíjazása előtt kiválasztották utódjának, és őt, a leendő szaktanácsadót a régi szaktanácsadó képezte ki erre a feladatra személyre szabott, egyéni továbbképzés keretében. Ez hosszabb folyamat volt, sok egyéni megbeszéléssel és hospitálással, a továbbképzés, majd később a funkció ellátása céljából az interjúalany órakedvezményt kapott. ${ }^{5}$

\footnotetext{
${ }^{5}$ Személyes közlés (2012): Interjú 2012. 12. 13-án egy Szászországból érkezett tanárral a miskolci Avasi Gimnáziumban.
} 
A belső minőségbiztosítás során az iskola igazgatója a tanárokat folyamatosan ellenőrzi. Ö a felelős az iskolafejlesztési koncepcióért, melynek része többek között a humán erőforrás fejlesztési terv (továbbképzési terv) létrehozása és végrehajtásának felügyelete is. Ebben az szerepel, hogy melyik pedagógus, mikor és milyen továbbképzésen vesz részt. Az igazgató és az iskola továbbképzési felelőse vagy felelösei az óralátogatáson és az óramegbeszéléseken túl ellenőrzik a pedagógus továbbképzési portfólióját, vagyis az elvégzett továbbképzések igazolásait és a továbbképzések dokumentumainak gyüjteményét.

\section{A német tanfelügyeleti rendszer általános jellemzése}

\section{Az oktatáspolitika a német tartományok belügye}

Oktatáspolitikai kérdésekröl, sőt a kultúra egészéröl Németországban nem az államszövetség szintjén döntenek. A kultúrpolitika a szövetségi államok belügye, ezek kulturális függetlensége és fennhatósága (Kulturhoheit der Länder) ugyanis az egyik legfontosabb német alkotmányos alapelv. ${ }^{6}$ A Német Szövetségi Köztársaság 16 szövetséges államból áll, ezeket tartományoknak szokás nevezni, de meg kell jegyezni, hogy ez a szó egyfajta függőséget sugall, jóllehet számos területen - ilyen a kultúra is - teljes függetlenséget élveznek. Ezt jól kifejezi, hogy egyes konkrét esetekben a tartományok nevét magyarra az ország szóval fordítjuk (például Bajorország, Szászország, Alsó-Szászország, vagy kisebb tartomány esetében: Szárvidék). A 16 német tartomány a német nevük betürendjében: Baden-Württemberg, Bajorország, Berlin, Brandenburg, Bréma, Hamburg, Hessen, Mecklenburg-Vorpommern, Alsó-Szászország, Észak-Rajna-Wesztfália, Rajna-Pfalz, Saarvidék, Szászország, Szász-Anhalt, Schleswig-Holstein, Türingia.

Az említett alkotmányos alapelv miatt a német tartományok között az oktatáspolitikai kérdésekben, az iskolarendszerben és a tanárképzés rendszerében számos különbség van, ezért érthető, hogy a tanfelügyeleti rendszert is különböző módon szervezik meg. A tanfelügyelet kérdését, vagyis az iskolák szakmai felügyeletét és minőségbiztosítását az egyes tartományok iskolatörvényei szabályozzák.

Valamennyi tartományban közös, hogy az iskolákat a magyar kormányhivatalhoz, oktatási hivatalhoz hasonló állami iskolai hivatalok felügyelik, ahol az iskolaügyekben képzett, fóállású hivatalnokok dolgoznak, akiknek elnevezése lehet, például: iskolai tanácsos, iskolafelügyelö hivatalnok, iskolai hivatal vezetője. Közvetlen

\footnotetext{
${ }^{6}$ Grundgesetz (Német Alkotmány) 1949. http://www.bundestag.de/bundestag/aufgaben/rechtsgrundlagen/grundgesetz/index.html Letöltve: 2013. 03. 02.

${ }^{7}$ Kultusministerkonferenz, Schulgesetze 2013.

http:/www.kmk.org/dokumentation/rechtsvorschriften-und-lehrplaene-der-laender/uebersichtschulgesetze.html Letöltve: 2013. 04. 16.
} 
munkatársaik közigazgatási és jogi szakemberek. Az iskolafelügyeleti hivatalnak kettős funkciója van: egyrészt ellenőrizhetik, másrészt közvetlenül utasíthatják is az iskolákat. A hivatal az egyes feladatok ellátására szakértőket kérhet fel, akik lehetnek szaktanácsadók vagy iskolalátogató tanfelügyelök.

Különbségek vannak abban a tekintetben is, hogy egyes tartományok az iskolafelügyeletet iskolatípusok szerint szervezik meg. Például Észak-Rajna Wesztfália ${ }^{8}$ tartományban eltérő felügyeleti struktúrát hoztak létre a gimnáziumok, szakközépiskolák, szakiskolák, kisegító iskolák és az általános iskolák számára.

Létezik ugyanakkor két legfelsőbb koordináló fórum. Ezek elnevezése „konferencia”, hasonló a magyar „Rektori Konferencia” elnevezéshez, ami azt sugallja, hogy egymástól teljesen független és önálló véleményalkotókról vagy döntéshozókról van szó.

\section{Közös egyeztetö fórumok a német államszövetség szintjén}

A Kultuszminiszterek Konferenciája a német tartományok legfelsőbb kulturális egyeztető fóruma. Célja a konszenzusteremtés azokban a kérdésekben, amelyek túlmutatnak a tartományi szinten. A honlapjukon megtalálhatók az egyes tartományok jogi normái, többek között minden egyes tartomány iskolatörvénye. Ezek a törvények jogilag pontosan és minden részletre kiterjedően szabályozzák az iskolaügy, ezen belül a tanfelügyelet lényeges kérdéseit. 2006-ban a Kultuszminiszterek Konferenciája hozta meg az új tanfelügyeleti rendszer felállításáról szóló határozatot. A Tanfelügyeleti Konferencia ${ }^{10}$ a német tartományok tanfelügyeleti hivatalainak fedöszervezete. Ez a szervezet koordinálja a tartományok tanfelügyelöinek együttmüködését az egyes iskolatípusokban.

A szervezet feladatai:

- Kezdeményezés és állásfoglalás iskolapolitikai és pedagógiai kérdésekben.

- Aktuális oktatásügyi trendek meghatározása és követése a tartományok jelentései alapján.

- Közremüködés a tanfelügyeleti munka feltételeinek kialakításában.

- Rendszeres információs anyagok kiadása.

- Tárgyalások az illetékes hatóságokkal és szervezetekkel.

- PR tevékenység: A tanfelügyeleti tevékenység bemutatása az oktatásügyben.

\footnotetext{
${ }^{8}$ Schulgesetz für das Land Nordrhein-Westfalen (Észak Rajna Westfália Iskolatörvénye) 2013.

http://www.schulministerium.nrw.de/BP/Schulrecht/Gesetze/Schulgesetz.pdf Letöltve: 2013. 04. 02.

${ }^{9}$ Kultusministerkonferenz, Schulgesetze 2013.

http://www.kmk.org/dokumentation/rechtsvorschriften-und-lehrplaene-der-laender/uebersichtschulgesetze.html Letöltve: 2013. 04. 16.

${ }^{10}$ Konferenz der Schulaufsicht in Deutschland (Német Iskolafelügyeleti Konferencia)

http://www.ksdev.de Letöltve: 2013.03. 17.
} 
A szervezet céljai:

- Koncepciós és korrekciós javaslatok megfogalmazása az oktatásügy alapkérdéseiben.

- A döntéshozók befolyásolása együttmüködve más szervezetekkel.

- A tartományi szintü szervezetek koordinálása a szövetségi állam szintjén.

- A tanfelügyeleti hatóságok szakmai érdekképviselete a szövetségi állam szintjén.

- Információcsere a tagok között.

- A tagság továbbképzése és a tanfelügyeleti munka professzionalizálása.

\section{Az önállósuló iskolák és a tanfelügyelet}

A tanfelügyelet rendszere, koncepciója sok változáson ment keresztül, és ez a folyamat napjainkban is tart (Bott, 2009, 2010, 2012). Hasonlóan a magyar tanfelügyeleti rendszerhez, a központi kérdés mindig is az volt, hogy a felügyelö és ellenőrző szerep legyen-e hangsúlyos, vagy inkább a támogató és tanácsadó funkció, illetve melyik milyen arányban legyen jelen. Egyre jobban vitatott kérdés, szabad-e és milyen mértékben ellenörzö-beavatkozó célból nyomást gyakorolni az iskolákra, vagy inkább minden eszközzel támogatni kell az iskolák önállósodását.

Az ezredforduló tájékán kezdődtek el Németországban azok a reformkísérletek, amelyek az iskolák nagyobb önállóságára irányultak. Nem autonóm (önálló) iskolákról beszélnek, mert ez teljes függetlenséget sugall, pedig az alkotmány kimondja, hogy ,az egész iskolarendszer az állam felügyelete alatt áll” (Grundgesetz, 1949). ${ }^{11}$ Inkább „önálló felelösségü" iskolákról, melyekben az iskola vezetője nagyobb döntési kompetenciával és iskolai-önkormányzati kompetenciával rendelkezik.

Az önálló felelösségü iskolák létrejötte a tanfelügyeleti rendszer koncepciójának megváltozását is maga után vonta. A legalapvetőbb változás a tanárok szakmai felügyeletében történt:

- Az önálló felelősségü iskolákban a vezetőnek nagy a szabadsága és egyben felelőssége. Feladata a iskolafejlesztési koncepció kidolgozása és értékelése az oktatás és a tanári munka színvonalának megítélése.

- Mindennek megfelelően a tanfelügyeletnek - ellentétben a korábbi gyakorlattal - ezzel már nem kell foglalkoznia, feladata csak annak az ellenörzése, hogy jó-e az iskola a minőségmenedzsment koncepciójának felépítése, alkalmazása és esetleges javítása.

- A tanfelügyelet már nem az egyes tanárt ellenörzi, hanem az iskolavezetöség munkáját.

\footnotetext{
${ }^{11}$ Grundgesetz (Német Alkotmány) 1949 1/7. cikkely http://www.bundestag.de/bundestag/aufgaben/rechtsgrundlagen/grundgesetz/index.html Letöltve: 2013. 03. 02.
} 
Ennek értelmében megváltozott a felügyeleti rendszer értelmezése. A pedagógusok ellenőrzése helyett elsősorban menedzserfunkciót jelent, vagyis tanácsadó és segítő szerepben, szolgáltatóként kell fellépnie.

$\mathrm{Az}$ „Önálló felelősségü iskola” koncepció keretében a modern tanfelügyelet feladatai a következők:

- Támogatni az önálló iskola önvezérlő mechanizmusát.

- Segíteni az iskola minőségfejlesztését.

- Ügyelni, hogy az iskola betartsa a jogi normákat.

- Támogatni az igazgatót a személyi kérdésekben.

- Iskolai ellenőrzés után megállapodásokat kötni, ezek betartását felügyelni.

- Összekötő kapocs lenni az iskolai és a kultuszminisztérium között.

- Külső partnerekkel együttmüködni a regionális oktatáspolitikai kérdésekben.

Napjaiknkban a következő kérdésekröl folynak viták e témakörben (Bott, 2012): Hajlandók-e az iskola vezetői felvállalni a megnövekedett felelősséget? Megvan-e az iskolaigazgatóknak a szükséges kompetenciájuk a megnövekedett felelösség felvállalására? Hogyan arányuljon egymáshoz az iskolaigazgatók és az öket felügyelö tanfelügyelők fizetése? Az álláspont az, hogy a kettőnek meg kell egyeznie. Átvehet-e az iskolaigazgatóktól egyes felelősségi köröket egy „Iskolakonferenciának” nevezett választott grémium az iskolák demokratizálódásának szellemében? A változások valóban szükségszerüek-e és valóban a minőség javulását szolgálják, vagy pedig csak pusztán takarékossági okokra vezethetők vissza?

A tanfelügyeleti rendszer átalakulása az egyes tartományokban eltérő mértékben valósult meg, illetve jelenleg is tart. A változások jogosságának igazolására Bott (2012) azt javasolja, hogy az alábbi lépésekben kerüljön sor a folyamat elemzésére:

- Határozzák meg pontosan az egyes szintek feladatait a kultuszminisztériumtól az iskolát felügyelő hatóságon át egészen az iskolákig.

- Mérjék fel a leírt feladatok ellátásához szükséges szakemberszükségletet.

- Tervezzék meg a szükséges átalakításokat a feladatok és a szakembergárda függvényében.

- Vizsgálják meg, hogy az átalakítás együtt járt-e a politikai döntéshozók által megcélzott költségcsökkentéssel.

\section{Hessen tartomány példája}

A 16 német tartomány között Hessen különös jelentőséggel bír. Hessen Németország kellős közepén fekszik, így pusztán földrajzi elhelyezkedésénél fogva is igen előnyös pozícióban van. Bár 21 millió négyzetkilométerével a német tartományok között csak a hetedik, hatmilliós lakosságával csak az ötödik helyen áll, gazdasági 
súlya az élvonalba helyezi. ${ }^{12}$ Az egy före jutó nemzeti jövedelem tekintetében 2012-ben a harmadik helyen állt. ${ }^{13}$ (Csak két városállam-tartomány, Hamburg és Bréma, az évszázadok óta leggazdagabb egykori Hansa-városok előzik meg) Hessen legnagyobb városa Frankfurt am Main, Berlin után a gazdasági és pénzügyi élet másik központja. Hessenben nemcsak fontos gazdasági és a pénzügyi innovációk történnek, de van anyagi és emberi erőforrás az oktatáspolitikai, oktatásügyi fejlesztésekre is.

Ezek a tények magyarázzák, hogy miért Hessen jár az élen a minőségfejlesztésben. A fővárosban, Wiesbadenben 2005-ben létrehozták a Minőségfejlesztési Intézetet, amelynek fontos szerepe van az oktatási sztenderdek és a tanártovábbképzési tanfolyamok akkreditációjának kidolgozásában. Kötelezően akkreditált, vagyis a minőségbiztosítás szempontjából garantáltan magas szintủ tanártovábbképzési kurzusok csak Hessenben vannak.

\section{A tanfelügyelet jogi szabályozása Hessenben: A Hesseni Iskolatörvény}

Mint minden német tartományban, Hessenben is az Iskolatörvény ${ }^{14}$ foglalja magában az iskolával kapcsolatos valamennyi jogi kérdést. A törvényben a hetedik rész, a Tanárok, Iskolavezetés, Iskolafelügyelet, második bekezdése foglalkozik az Iskolafelügyelet jogi szabályozásával: „A tanfelügyeleti hatóságoknak az a feladata, hogy az iskolai munka minőségét, különösen a sztenderdek teljesítését és a bizonyítványok összehasonlíthatóságát értékelési eljárás (...) révén garantálják. Tanácsokkal segítik az iskolát abban, hogy feladatait önállóan lássa el, célmegállapodásokat kötnek, amelyekben a tanfelügyeleti látogatás eredményeit figyelembe veszik. Az iskolák a célmegállapodások révén adnak számot munkájukról a felügyeleti hatóságnak." 15

A 94. § megnevezi a tanfelügyelet ellátására jogosult személyeket: fóállású, iskolaügyekben és közigazgatási ügyekben képzett hivatalnokok, akik jól ismerik az általuk felügyelt iskolatípust. A tanfelügyeleti hatóság foglalkoztat még iskolapszichológusokat, akiknek a feladata a megelőzés és a tanácsadás, valamint szaktanácsadókat, akik fóállású pedagógusok.

\footnotetext{
${ }^{12}$ Tatsachen über Deutschland (2010/2011)

http://www.tatsachen-ueber-deutschland.de/de/inhaltsseiten-home/zahlen-fakten/geografie.html Letöltve: 2013. 04. 14.

${ }^{13}$ Bruttoinlandsprodukt, a német tartományok nemzeti jövedelme 2012

http://www.statistik-bw.de/VolkswPreise/Indikatoren/VW wirtschaftskraft.asp Letöltve: 2012. 04. 20.

${ }^{14}$ Hessisches Schulgesetz (Hessen Iskolatörvénye) 2005, utolsó változata: 2012. Kultusministerkonferenz, Schulgesetze 2013 http://www.kmk.org/dokumentation/rechtsvorschriften-und-lehrplaene-derlaender/uebersicht-schulgesetze.html Letöltve: 2013. 04. 16.

${ }^{15}$ Hessisches Schulgesetz (Hessen Iskolatörvénye) 76. o. 2005, utolsó változata: 2012. Kultusministerkonferenz, Schulgesetze 2013 http://www.kmk.org/dokumentation/rechtsvorschriften-und-lehrplaeneder-laender/uebersicht-schulgesetze.html Letöltve: 2013. 04. 16.
} 
A 95. és 96. § leírja a tanfelügyelet szintjeit: Az alsó szintủ tanfelügyeleti hatóság a (Hesseni) Oktatási Hivatal, melynek hatásköre az iskolák szakmai és szolgálati felügyelete. A felső szintü tanfelügyeleti hatóság a Kultuszminisztérium ami közvetett és közvetlen felügyeletet gyakorolhat az iskolákon. Az iskolafenntartók jogi felügyeletét az illetékes önkormányzati hatóságok gyakorolják.

A törvény tizedik részének (Az iskola alkotmánya) első fejezete mondja ki az iskolák önkormányzatának és önállóságának alapelvét: „Az iskola az állami felelősségvállalás, valamint a jogi és igazgatási elöirások keretei között önálló

- az iskolai élet és az oktatás megtervezésében és megvalósításában,

- a nevelésben,

- belső ügyeinek vezetésében, szervezésében és igazgatásában.” (127. §, 96. o.)

A 127 a-d. §-ok leírják, hogy az iskolák bizonyos feltételek teljesítése estén átalakulhatnak Önálló iskolává, ${ }^{16}$ amit az iskolafelügyeleti hatóság állásfoglalása alapján a Kultuszminisztérium engedélyez. Az Önálló iskola munkáját évenként felülvizsgálják és értékelik egy kidolgozott minőségbiztosítási rendszer alapján.

\section{A modern tanfelügyelet Hessen tartományban}

A német tanfelügyelet a mai formájában még nem olyan régi. 2006-ban, a PISA felmérések bevezetése után határozta el a Kultuszminiszeterek Konferenciája, hogy az iskolákat rendszeres monitorozásnak vetik alá. Ezt megelőzte 2005-ben a kísérleti szakasz, s 2006. szeptember 1-jén bevezették Hessen tartományban a modern tanfelügyeletet. Azóta tartják szükségesnek és elengedhetelennek az összehasonlító vizsgálatokat tartományi, tartományok közötti (például a Hessennel szomszédos tartományok Közép-Németországban), államszövetségi (Németország minden tartománya) és nemzetközi (az Európai Unió tagállamai) szinten.

Maga a tanfelügyelet Németországban több évszázados múltra tekinthet viszsza. A mai Hessen tartományban már a reformáció elötti időkben volt tanfelügyelet. Luther és Melanchton már erre a meglévő hagyományra építve javasolta, hogy évente vizsgálják felül az oktatást, ellenőrizzék a tanárok és az iskolavezetés munkáját. A tanfelügyelet évszázadokig egyházi kézben volt. Az állami tanfelügyelet rendszerét elsőnek a történelmi Poroszországban vezették be 1872-ben azzal a céllal, hogy az állam közvetlen felügyeletet gyakoroljon az általa fenntartott iskolákban. Azonban az egyházi és az állami tanfelügyeletben rejlö ellentmondás sok feszültséggel és konfliktussal terhelt volt. 1919-re teljesen számüzték az egyházi tanfelügyeletet az állami iskolákból.

\footnotetext{
${ }^{16}$ Eigenverantwortliche Schule, (2011)

https://docs.google.com/viewer?a=v\&q=cache:gRO2vhmGJysJ:www.landesschulbehoerdeniedersachsen.de/organisation/neuausrichtung-2011/schule-und-schulaufsicht/Eigenverantwortliche Letöltve: 2013. 03. 27.
} 
A német tartományok között Hessen különleges helyzetben van. 2005 óta - ahogy az előzőekben már említettük - itt müködött egész Németország viszonylatában különleges jelentőségü Minőségfejlesztési Intézet, ami a pedagógiai innovációban élen járt, főként a teljesítményértékeléssel, minőségmenedzseléssel kapcsolatos kutatások, valamint az ezekről szóló információk professzionális közlése területén. 2013. január 1-jén az önálló intézet megszünt, és része lett a (Hesseni) Országos Iskolahivatal és Tanárakadémiának. ${ }^{17}$

Hessen kormánya 2012. szeptember 27-én fogadta el „Az iskolaigazgatás szervezeti struktúraváltásának reformjá"-t. Az újonnan megalapított intézmény az alábbi korábbi intézményeket fogta egy szervezeti egységbe: a Tanárképzési Hivatalt, a Minöségfejlesztési Intézetet, ami nyolcéves, igen eredményes múltra tekinthet vissza és Hessen tartomány 15 állami oktatási hivatalát, amelyek az egyes járásokban, illetve nagyvárosokban maradtak. Elnevezésük: kirendeltség pontosan körülhatárolt regionális illetékességgel.

Az új intézményben egy központi és három alosztály müködik, melyek a következők:

- Központi osztály: Központi szolgáltatási osztály

- I. alosztály: Tanügyi felügyelet és tanácsadás

- II. alosztály: Tanárképzési és Erőforrás-fejlesztési Akadémia

- III. alosztály: Minőségfejlesztés és evaluáció

Ezzel Hessenben létrejött egy olyan központi intézmény, ami az iskolák és a tanárok számára sokoldalú támogatási, visszacsatolási és minőségbiztosítási lehetőséget tud biztosítani.

Az új intézmény létrehozásának az volt a célja, hogy

- a különböző feladatterületek között szoros együttmüködést hozzanak létre,

- átlátható legyen a strukturális felépítés és világosak legyenek a felelősségi területek,

- a hesseni iskolák a küszöbön álló kihívásokhoz széles körü támogatást kapjanak,

- a továbbképzési szükségleteket feltárják, és továbbképzési lehetőségeket teremtsenek,

- az igazgatást összességében hatékonyabban szervezzék meg,

- összekötő kapocs legyen a Kultuszminisztérium és az iskolák között.

Az önálló felelősségü iskolák vonatkozásában az intézmény így definiálja a feladatkörét: „A reform kiinduló pontja a hesseni önálló (felelősségü) iskola koncepció. Az az egyre erösödö tendencia, hogy az iskoláknak legyen egyéni arculata és profilja, nagyobb önállósága az oktatás megszervezésben és a személyi kérdésekben, hogy az iskolavezetésnek erősödjön a felelőssége, szükségessé teszi az iskolai kötségvetés az iskolai támogató rendszer újraértelmezését. Az önállósodó iskolák-

\footnotetext{
${ }^{17}$ Landesschulamt und Lehrkräfteakademie 2013. www.lsa.hessen.de Letöltve: 2013. 03. 25.
} 
nak szükségük van egy jól müködő és összehangolt támogatói rendszerre világos illetékességekkel és egyértelmü elóírásokkal. Ennek az elvárásnak akar az Országos Iskolahivatal megfelelni." 18

\section{A Hesseni Iskolaminőségi Referenciakeret ${ }^{19}$}

A hesseni Minőségfejlesztési Intézet kifejlesztett egy referenciarendszert az iskolai minőségmenedzsment számára, amely az aktuális oktatáskutatási eredmények alapján hét területen írja le az iskolaminőségi kritériumokat, vagyis azt, hogy milyen minőségi elvárásoknak és követelményeknek kell megfelelniük az iskoláknak egyes területeken. Középpontban a „Tanítás és tanulás” területe áll. A referenciakeret nyitott, az aktuális elméleti koncepciók, empirikus kutatások és gyakorlati tapasztalatok alapján folyamatosan fejlesztik. A referenciakeret célja egyrészt, hogy a belső ellenőrzés során az iskoláknak legyen módjuk a minőség folyamatos ellenőrzésére, értékelésére és javítására. A belső iskolai ellenőrzés eljárásait és eszközeit külön kiadványban dolgozták ki az iskolák számára, ami az intézet honlapján megtalálható. Másrészt azt szolgálja, hogy a hesseni tanfelügyeletnek egységes szempontrendszer álljon rendelkezésére az ellenőrző iskolalátogatások során. 2011-től az iskolákat eszerint a speciálisan kidolgozott alapelvek szerint értékelik.

\section{A tanfelügyeleti látogatás menete}

A tanfelügyeleti látogatás négy szakaszból áll: előkészítés, iskolalátogatás, jelentéskészítés és a jelentés bemutatása, célmegállapodások kialakítása.

\section{Első szakasz: Elökészités}

- 11 héttel az ellenőrző látogatás előtt az iskolát az oktatási hivatal levélben értesíti annak időpontjáról. Ebben közlik, hol találhatók meg az elektronikusan lehívható információk és anyagok a látogatás céljairól és lefolyásáról.

- 8-9 héttel a látogatás előtt a látogató team vezetője telefonon felveszi a kapcsolatot az iskola vezetőjével, megbeszéli vele a szervezési teendőket és a látogatás menetét, valamint azt, hogy legyen-e és mi legyen a látogatás súlypontja.

- 7 héttel a látogatás elött elküldik az iskolának a kérdőíves felmérés hozzáférési kódjait.

\footnotetext{
${ }^{18}$ www.lsa.hessen.de, über uns

${ }^{19}$ Hessischer Referenzrahmen Schulqualität, Verfahren und Instrumente

http://qualitaetsentwicklung.lsa.hessen.de/irj/servlet/prt/portal/prtroot/slimp.CMReader/HKM_15/IQ_ Internet/med/2df/2df0380b-e 700-d21f-012f-31e2389e4818 Letöltve: 2013. 03. 28.
} 
- 4-6 héttel a látogatás előtt lezajlik az online kérdővek kitöltése, az iskola elküldi a hivatalnak a szükségek dokumentumokat és információkat, amelyeket a látogató team elemez.

\section{Második szakasz: Iskolalátogatás}

Az iskolalátogatás kettő-négy napot, tagiskolánál egy napot vesz igénybe. Délelőtt az iskola bejárásával kezdődik. Az első nagyszünetben a látogató team köszönti a tanárokat a tanári szobában, és röviden ismerteti a látogatás céljait. Délelőtt óralátogatások folynak. A látogatók kitöltik az Óramegfigyelési és elemzési ürlapot. A látogatók interjúkat is folytatnak, ezeket dokumentálják, de a jelentés elkészítése után a válaszokat megsemmisítik. A dokumentumelemzés során betekintenek az iskolai dokumentumokba. A látogatási napokon többször kerül sor megbeszélésekre. Zárásként visszajelzést adnak az iskolavezetésnek a látogatásról, de eredményeket ekkor még nem közölnek.

\section{Harmadik szakasz: A jelentés elkészitése}

A látogató team a Hesseni Iskolaminőségi Referenciakeret alapján a megfigyeléseket és eredményeket egy jelentésben összegzi. Ebben helyet kap egy visszajelzés is az iskola által választott szakmai súlypontról, valamint az előző látogatás óta történt fejődésröl.

- 6 héttel a látogatás után a jelentést megküldik az iskolának az esetleges tárgyi hibák három nap alatt történő kijavítására.

- 6-8 héttel a látogatás után megküldik a kész jelentést az iskolának és a felügyelő hatóságnak.

\section{Negyedik szakasz: A jelentés bemutatása és célmegállapodások}

A kész jelentés kézhezvételétől számított hat héten belül az iskolavezetés eredményértékelő iskolai konferenciát hív össze, amin az illetékes felügyelö hivatal vezetöje vesz részt és a látogató team is jelen lehet. A konferencia célja, hogy megegyezzenek a fejlesztési irányról amit célmegállapodások formájában rögzítenek. Ezek bekerülnek az iskola programjába is. A célmegállapodásokat az iskolavezető és a hivatalvezető írja alá, amelyben rögzítik, hogy mely területeken és hogyan kell a fejlesztésnek történnie. A célmegállapodások teljesítésében a hivatalnak támogatnia kell az iskolát.

\section{A tanfelügyeleti látogatás módszerei és eszközei}

A következőkben a már idézett honlap alapján bemutatjuk, milyen módszereket és eszközöket alkalmaznak a tanfelügyeleti látogatás során. 
Az iskolai dokumentumok elemzése

A következő dokumentumok elemzésére kerülhet sor: helyi tanterv, honlap, határozatok, szabályok, például nevelés, tehetséggondozás alapelvei, házirend, célmegállapodások az oktatási hivatallal, belső ellenőrzés és értékelés, továbbképzési terv, helyettesítési koncepció, osztályok és tanárok órarendjei, terembeosztás, belső iskolai információk, az ikolaigazgató közlései, jegyzőkönyvek a konferenciákról és megbeszélésekről, tantervek, curriculum, tanári jelentések, osztálynaplók, kurzusnaplók, időponttervek, tehetséggondozási és felzárkóztatási tervek, osztályok és kurzusok dolgozatai, prospektusok, brossúrák, sajtótudósítások.

\section{Óralátogatások}

A látogatások fontos részét képezik az óralátogatások. Általában a látogatás napjain az órarendben szereplő órák 50 százalékának, de legalább 12, tagiskolában legfeljebb kilenc óra húszperces látogatásra kerül sor. Az első meglátogatott órán a team minden tagja jelen van és összehangolják a megfigyelési szempontjaikat. Fontos megjegyezni, hogy nem az egyes tanár vagy tanulói csoport megfigyeléséről van szó, hanem az oktatás minőségi jellemzőinek megragadásáról. A meglátogatott órán a látogató kérdőívet tölt ki, ami a Referenciakeret Tanitás és tanulás szempontrendszerének értelmében az alábbiakra tér ki:

- a szaktárgyi és általános kompetenciák fejlesztése;

- strukturált és átlátható tanítási és tanulási folyamatok;

- a heterogén tanulócsoport kezelése;

- tanulást segítő tanórai atmoszféra.

Az egyes szempontokat négyes skálán értékelik. Azonban a tanárok nem kapnak visszajelzéseket az órájukról, mert a cél nem az egyes tanár értékelése, hanem az, hogy a látogatók feltérképezzék az iskolát a gyakorlati életben jellemző tanítási minőséget. Az eredményeket táblázatos formában összegzik, és belefoglalják a jelentésbe.

\section{Online kérdöivek}

Az online kérdőívek az iskola munkájában érdekelt, érintett célcsoportok számára készültek: iskolavezetőség, tanulók (az általános iskola 3. osztálytól, felső tagozat, középiskola, szakképző iskola), tanárok (általánosan képző iskolák és szakképző iskolák), szülők, a szakképzésben részt vevő partnerek. A kérdőívek az iskola honlapján elérhetőek. Az online kérdőívek eltérö itemszámúak, a hesseni referenciakeret szerinti kérdéseket tartalmazzák, melyekre $1=$ nem jellemzö, $2=$ inkább nem jellemző, $3=$ inkább jellemzö, 4=jellemző válaszok adhatók. Az iskolavezetés szöveges kommentárt is tehet. Az online kérdőívek eredményeit az iskola megismerheti. 


\section{Interjúk}

Két tanfelügyelö folytat interjúkat az alábbi célcsoportokkal: iskolavezetés, tanárok, szülők, tanulók, nem pedagógiai dolgozók (például portás, irodai dolgozók), iskolai szociális munkások (ha vannak), a szakképző üzemek képviselői (szakképző iskolák esetében). Az interjúk időtartama 30-90 perc, amelynek során az egyik tanfelügyelö kérdez, a másik rögzíti a válaszokat. Az interjúk célja kizárólag az adatszerzés, az iratokat az eljárás végén megsemmisítik.

\section{A tanfelügyeleti látogatások évkönyve}

Minden évben egy évkönyvben összefoglalják az azévi iskolalátogatások eredményeit, és az oktatáspolitika döntéshozók rendelkezésére bocsátják.

\section{Németország és Hessen tartomány tanfelügyeleti rendszerének tanulságai}

A német tanfelügyeleti rendszer tanulságai magyar viszonylatban azért érdekesek, mert 2013 szeptemberétől Magyarországon is be kívánják vezetni az iskolák minőségellenőrzési rendszerét. A német tanfelügyeleti rendszer sok szempontból mintaként szolgálhat a bevezetendő magyar tanfelügyeleti rendszer számára. Nagyon tanulságos, hogy Németországban nem minősítik sem az iskolákat, sem a tanárokat, hanem fejlesztésre szoruló területeket állapítanak meg és ajánlásokat (ún. célmegállapodásokat) tesznek a fejlesztés érdekében. Ennek azonban feltétele a tanárképzésben alkalmazott pályaalkalmassági szürési rendszer, valamint az iskolaigazgatók és a pedagógusok kompetenciáinak fejlesztését szolgáló mennyiségét és minőségét tekintve gazdag továbbképzési kínálat. A tanfelügyeleti rendszer sikeres müködése ennélfogva szoros kapcsolatban áll a tanárképzés és a tanártovábbképzés teljes spektrumával.

\section{Irodalom}

Bikics Gabriella (2011): Sztenderdek és pályaalkalmasság a német tanárképzésben. In: Falus Iván (szerk.): Tanári pályaalkalmasság - kompetenciák - sztenderdek. Nemzetközi áttekintés. Eszterházy Károly Föiskola, Eger, 181-205.

Bott, W. (2009): Grenzen der Selbständigkeit von Schule. Schulverwaltung HE/RP 6. 190-191.

Bott W. (2010): Zurück in die Zukunft - Schulaufsicht in Hessen. Schulverwaltung HE/RP 11. 350-351.

Bott, W. (2012): Zur Schulaufsicht in Deutschland Anmerkungen zu aktuellen Veränderungen. Schulverwaltung. HE/RP 7-8. 221-222.

Dubs, R. (2003): Controlling und Beratung. Die Zukunft der Schulaufsicht. forum schule Magazin für Lehrerinnen und Lehrer 2. www.forum-schule.de Letöltve: 2013. 03. 17. 